\title{
POTENSI, EFEKTIVITAS DAN KONTRIBUSI PAJAK HOTEL TERHADAP PENDAPATAN ASLI DAERAH KOTA YOGYAKARTA
}

\author{
Dita Dwi Agustina Darmanto, \\ Indro Herry Mulyanto, \\ Suratna \\ email : ditadwii@gmail.com \\ Universitas Pembangunan Nasional "Veteran" Yogyakarta
}

\begin{abstract}
This study aims to determine the potential hotel tax that actually has in Yogyakarta City, how far the level of hotel tax effectiveness and how much the hotel tax contribution in the City of Yogyakarta.

This research is included in the type of quantitative descriptive research. The population in this study are all hotels in the city of Yogyakarta. The data used in this study are secondary data obtained from the Regional Finance and Assets Agency, Yogyakarta Central Statistics Agency. The sampling technique used is non probability sampling by means of purposive sampling based on selected criteria. The analysis technique uses the analysis of hotel tax potential calculations, analysis of hotel tax effectiveness calculations and analysis of hotel tax contribution calculations.

The results of this study point out that the comparison between hotel tax potential with the realization of hotel tax revenue within five years is from years 2011-2015 there is a big difference, with a potential hotel tax of Rp. 425,219,891,636 and realized hotel tax revenue of $R p$. 335,529,045,226, then the local government lost the potential of $R p$. $89,690,846,410$, from the two hotel classifications in the city of Yogyakarta star hotels that have a greater proportion of potential than non-star hotels. The level of effectiveness shows that hotel tax revenue shows the average percentage is still below $100 \%$ with the criteria "Not Effective" so that it can be concluded that the realization of hotel tax revenue in the city of Yogyakarta has not yet reached the maximum potential, while the level of hotel tax contribution to local revenue in The city of Yogyakarta in accordance with the targets set by the local government shows a percentage above 4\% with the criterion "Very Contribute", so it can be concluded that the hotel tax contribution also contributes greatly to local original income in the city of Yogyakarta.
\end{abstract}

Keywords: Potential Analysis, Effectiveness, Contribution, Hotel Tax, Regional Original Revenue 


\section{PENDAHULUAN}

\section{Latar Belakang}

Pendapatan Asli Daerah (PAD) adalah salah satu sumber keuangan daerah, seperti yang dijelaskan dalam Undang- Undang Nomor 33 tahun 2004 tentang perimbangan keuangan antara pemerintah pusat dan pemerintah daerah telah menetapkan bahwa salah satu pendapatan asli daerah adalah Pajak Daerah. Yang selanjutnya disebut, Pajak Daerah adalah kontribusi wajib kepada daerah yang terutang oleh orang pribadi atau badan yang bersifat memaksa yang berdasarkan Undang-undang, dengan tidak mendapatkan imbalan secara langsung dan digunakan untuk keperluan daerah bagi sebesar- besarnya kemakmuran rakyat (Undang- Undang Nomor 28 tahun 2009).

Berdasarkan Undang-Undang Nomor 28 tahun 2009 tentang Pajak Daerah dan Retribusi Daerah, Pajak Daerah terbagi menjadi dua jenis, yaitu Pajak Provinsi terdiri dari Pajak Kendaraan Bermotor, Bea Balik Nama Kendaraan Bermotor, Pajak Bahan Bakar Kendaraan Bermotor, Pajak Air Permukaan, dan Pajak Rokok. Sedangkan Pajak Kabupaten/Kota terdiri dari Pajak Hotel, Pajak Restoran, Pajak Hiburan, Pajak Reklame, Pajak Penerangan Jalan, Pajak Mineral Bukan Logam dan Batuan, Pajak Parkir, Pajak Air Tanah, Pajak Sarang Burung Walet, Pajak Bumi dan Bangunan Perdesaan dan Perkotaan, dan Bea Perolehan Hak Atas Tanah dan Bangunan. Tetapi tidak semua pajak daerah tersebut yang terlaksana dengan lancar dan efektif, hal ini disebabkan karena penerimaan daerah yang potensial hanya bersumber dari beberapa pajak saja, seperti Pajak Hotel, Pajak Restoran, Pajak Hiburan.

Pajak Hotel di Kota Yogyakarta memiliki angka pertumbuhan sebesar 25,95\%, dan beberapa pajak yang lain juga mengalami pertumbuhan yang cukup baik dari tahun ke tahun sehingga angka pertumbuhan yang dihasilkan cukup tinggi. Meskipun persentase pertumbuhannya masih menempati posisi ketiga, namun jika dilihat dari sisi angka menunjukkan nilai rupiah yang paling besar, sektor ini mempunyai peluang prospek yang bagus untuk penerimaan daerah karena dengan meningkatnya sektor pariwisata ini juga akan meningkatkan penerimaan Pajak Hotel.

Hubungan yang berkaitan antara sektor pariwisata dan sektor perpajakan 
menunjukkan bahwa didalam sektor pariwisata terdapat sarana penunjang wisata yaitu objek wisata, hotel dan restoran, serta seni dan budaya. Dari setiap penggunaan sarana wisata tersebut dikenakan pajak kepada para penggunanya. Dengan demikian, semakin banyak masyarakat ataupun wisatawan yang melakukan kegiatan pariwisata di Kota Yogyakarta, maka semakin besar pula potensi pendapatan bagi sektor pajak. Dengan adanya alasan tersebut, Kota Yogyakarta memiliki fasilitas penunjang dari sektor pariwisata terutama hotel. Adanya ketersediaan hotel di Kota Yogyakarta dapat menunjukkan perkembangan kegiatan perekonomian dan peluang lainnya.

Petugas Badan Pengelolaan Keuangan dan Aset Daerah Kota Yogyakarta dalam melaksanakan pemungutan Pajak Hotel, berorientasi pada target yang telah disusun sebelumnya, sehingga memungkinkan target yang ditetapkan selalu bisa dicapai dengan realisasi penerimaan pajak hotel yang lebih besar. Selisih yang sangat besar dari tahun ke tahun serta tidak stabilnya persentase pertumbuhan target penerimaan dan menimbulkan permasalahan dengan melihat pada persentase pertumbuhan yang dihasilkan. Hal ini menunjukkan penetapan target tidak berdasarkan pada potensi Pajak Hotel yang dimiliki. Penerimaan Pajak Daerah di Kota Yogyakarta masih belum optimal dan masih dapat ditingkatkan lagi. Oleh karena itu, optimalisasi potensi dan efektivitas Pajak Hotel sangat diperlukan untuk meningkatkan kontribusi penerimaan pajak daerah yang selanjutnya akan meningkatkan Pendapatan Asli Daerah. Berdasarkan dengan latar belakang tersebut, maka peneliti tertarik untuk menganalis potensi pajak hotel, efektivitas pemungutan pajak dan kontribusi penerimaan pajak hotel terhadap pendapatan asli daerah.

\section{Landasan Teori}

\section{1) Potensi Pajak Hotel}

Potensi pajak hotel adalah hasil temuan pendataan dilapangan yang berkaitan dengan jumlah serta frekuensi objek pajak yang kemudian dikalikan dengan tarif dasar pajak. (Sulistyo, 2013)

Menurut Mahmudi (2010:48) dalam Sugiarto dkk (2015), Potensi adalah 
sesuatu yang sebenarnya sudah ada, hanya belum di dapat atau diperoleh di tangan. Untuk mendapatkan atau memperolehnya perlu upaya-upaya tertentu, misalnya untuk potensi pajak perlu dilakukan upaya pajak (tax effort). Jika dikaitkan dengan Pendapatan Asli Daerah maka potensi adalah suatu kesanggupan pemerintah daerah dalam membiayai penyelenggaraan pemerintahan, pelaksanaan pembangunan, dan kegiatan kemasyarakatan di daerah dalam pencapaian tujuan Negara. Dimana potensi diharapkan dapat menghasilkan sesuatu yang berguna bagi daerah yang ditujukan untuk peningkatan kemajuan pembangunan daerah.

Potensi Pajak Hotel sangat menentukan besarnya Pajak Daerah yang dapat dipungut, dengan demikian besarnya Potensi Pajak Hotel perlu diketahui untuk menetapkan besarnya penerimaan pajak pada suatu periode. Hal ini akan memudahkan perencaan dan mengendalikan pelaksanaan pemungutan Pajak Hotel itu sendiri (Prakosa, 2005: 145)

Menurut Devas (1999:143) dalam Sugiarto dkk (2015), ada tiga tolak ukur yang bisa dilihat dalam mengukur potensi suatu daerah sebagai dasar dalam pengenaan suatu Pajak Daerah, yaitu Upaya Pajak, Hasil Guna, Daya Guna. Untuk menghitung potensi pajak hotel digunakan langkah-langkah yang disampaikan oleh Harun (2003) dalam Sugiarto dkk (2015) sebagai berikut:

a. Mengetahui jumlah hotel

b. Mengidentifikasi tipe kelas hotel (Bintang, Melati, Resort, Homestay dan Pondok wisata), jumlah kamar dan tarif kamar untuk mengetahui tarif kamar rata- rata

c. Mengetahui jumlah hari dalam setahun

d. Memperoleh omzet hotel dan mengkalikan dengan tarif pajak hotel

Untuk menghitung potensi Pajak Hotel, dapat menggunakan rumus yang disampaikan oleh Harun (2003) dalam Sulistyo (2013) sebagai berikut:

Potensi Pajak = A x B x C x D x E Keterangan :

A : Jumlah kamar hotel 
B : Tarif kamar rata-rata

C : Jumlah hari dalam 1 tahun

D : Tingkat Hunian Kamar

E : Tarif pajak hotel (10\%)

Pengukuran potensi pajak sangat mempengaruhi oleh semua tahap kegiatan (fungsi) administrasi pendapatan pajak/retribusi seperti tahap-tahap pendapatan, penetapan penyetoran dan pembukuan.

\section{2) Efektivitas Pajak Hotel}

Menurut Devas dalam Prakosa (2005:142), efektivitas yaitu imbangan antara pendapatan (pajak atau retribusi) yang sebenarnya terhadap pendapatan yang potensial dari suatu pajak yaitu dengan anggapan bahwa mereka yang seharusnya membayar, dengan jumlah yang seharusnya dibayarkan, benar-benar memenuhi kewajibannya.

Efektivitas digunakan untuk mengukur suatu hubungan hasil pungutan suatu pajak dengan tujuan atau potensi riil yang telah dimiliki suatu daerah. (Maulana, 2013)

Menurut Mardiasmo (2002) dalam Sugiarto dkk (2015), Efektivitas digunakan untuk mengukur hubungan antara hasil pungutan suatu pajak dengan tujuan atau target yang telah ditetapkan.

Cara untuk mengukur efektivitas pemungutan pajak adalah sebagai berikut: (Sugiarto dkk, 2015)

$$
\text { Efektivitas }=\frac{\text { Realisasi Penerimaan Pajak Hotel }}{\text { Potensi Penerimaan Pajak Hotel }} \times 100 \%
$$

Dari pengertian efektivitas tersebut disimpulkan bahwa efektivitas bertujuan untuk mengukur rasio keberhasilan, semakin besar rasio maka semakin efektif, standar minimal rasio keberhasilan adalah $100 \%$ atau 1 (satu) dimana realisasi sama dengan target yang telah ditentukan. Rasio dibawah standar minimal keberhasilan dapat dikatakan tidak efektf. (Sugiarto dkk, 2015) 
Tingkat efektifitas dapat digolongkan kedalam beberapa kategori yaitu: Kontribusi digunakan untuk mengetahui sejauh mana pajak daerah memberikan sumbangan dalam penerimaan PAD. (Ardiles, 2015)

Untuk mengetahui seberapa besar kontribusi yang dapat disumbangkan dari Pajak Hotel terhadap pendapatan asli daerah Kota Yogyakarta dapat digunakan rumus sebagai berikut (Pujiasih dan Wardani, 2014):

a. Hasil perbandingan tingkat pencapaian diatas 100 persen berarti sangat efektif

$$
\text { Kontribusi }=\frac{\text { Penerimaan Pajak Hotel }}{\text { Jumlah PAD periode tertentu }} \times 100 \%
$$

b. Hasil perbandingan tingkat pencapaian 100 persen berarti efektif

c. Hasil perbandingan tingkat pencapaian dibawah 100 persen berarti tidak efektif.

\section{3) Kontribusi Pajak Hotel}

Menurut Kamus Besar Bahasa Indonesia, pengertian kontribusi adalah sumbangan; sedangkan menurut Kamus Ekonomi dalam Ardhiansyah, dkk (2014) kontribusi adalah sesuatu yang diberikan bersama-sama dengan pihak lain untuk tujuan biaya, atau kerugian tertentu atau bersama. Sehingga kontribusi disini dapat diartikan sebagai sumbangan yang diberikan oleh Pajak Hotel terhadap Penerimaan Pendapatan Asli Daerah.

Kontribusi adalah sumbangan, sokongan atau dukungan terhadap suatu kegiatan. Kontribusi merupakan suatu ukuran untuk mengetahui seberapa besar sumbangan pajak daerah dalam meningkatkan Pendapatan Asli Daerah. Untuk melihat kriteria kontribusi pajak hotel dapat dilihat dalam tabel 1. 
Klasifikasi Kriteria Kontribusi

\begin{tabular}{|c|l|}
\hline Persentase & \multicolumn{1}{|c|}{ Kriteria } \\
\hline $0-0,9 \%$ & Relatif Tidak Mempunyai Kontribusi \\
\hline $1-1,9 \%$ & Kurang Mempunyai Kontribusi \\
\hline $2-2,9 \%$ & Cukup Mempunyai Kontribusi \\
\hline $3-3,9 \%$ & Mempunyai Kontribusi \\
\hline$>4 \%$ & Sangat Berkontribusi \\
\hline
\end{tabular}

Sumber: Fuad Bawazier (1999) dalam Sugiarto, Edy (2016)

Kontribusi dilakukan dengan membandingkan penerimaan pajak hotel periode tertentu dengan penerimaan PAD periode tertentu pula. Jika semakin besar angka persentase kontribusinya maka semakin besar pula pajak hotel memberikan kontribusi terhadap Pendapatan Asli Daerah.

\section{Metode Penelitian}

\section{a. Jenis Penelitian}

Jenis penelitian ini adalah deskriptif dengan pendekatan kuantitatif. Deskriptif yang dimaksud disini adalah menggambarkan data keuangan pajak daerah pada masa tertentu.

\section{b. Objek Penelitian}

Objek dalam penelitian ini adalah salah satu sumber yang berguna bagi Pendapatan Asli Daerah yaitu Pajak Hotel. Dimana bagian yang akan diteliti dari Pendapatan Asli daerah adalah Potensi Pajak Hotel, Efektivitas dan Kontribusi Pajak Hotel yang ada di wilayah Kota Yogyakarta.

\section{c. Sumber Data}

Jenis data yang digunakan dalam penelitian ini adalah data sekunder yaitu data yang didapatkan dari Badan Pengelolaan Keuangan dan Aset Daerah Kota Yogyakarta dan 
Badan Pusat Statisik Kota Yogyakarta.

\section{d. Teknik Pengumpulan Data}

Dalam penelitian ini menggunakan literatur seperti jurnal-jurnal yang bersangkutan dengan penelitian ini, serta dokumentasi atau buku yang berbentuk laporan keuangan pajak daerah.

\section{e. Populasi dan Sampel}

1) Populasi

Pada penelitian ini populasinya adalah seluruh hotel yang ada di daerah Kota Yogyakarta termasuk hotel bintang dan hotel non bintang/melati.

\section{2) Sampel}

Sampel yang digunakan dalam penelitian ini adalah beberapa dari jumlah populasi hotel berbintang dan hotel non bintang/melati yang memenuhi kriteria, dalam periode tahun 2011-2015.

\section{f. Teknik Sampling}

Penelitian ini menggunakan teknik non probability sampling, dengan cara purposive sampling yaitu teknik penentuan sampel dengan pertimbangan atau kriteria tertentu (Sugiyono, 2007: 122). Sebagaimana kriteria yang dipilih dalam sampel penelitian ini, seperti:

1. Hotel terdaftar pada Wajib Pajak Hotel, Dinas Pariwisata dan pada Badan Pengelolah Keuangan dan Aset Daerah di Kota Yogyakarta

2. Data penerimaan Pajak Hotel tahun 2011-2015 yang tersedia lengkap

3. Hotel ataupun penginapan yang masih aktif beroperasi sampai Desember 2015

4. Hotel ataupun penginapan yang memiliki pergantian waktu penghunian 1X24 jam. 


\section{g. Teknik Analisis Data}

\section{Analisis Perhitungan Potensi Pajak Hotel}

Dalam langkah menghitung potensi pajak hotel berbintang dan non-bintang, perlu diketahui terlebih dahulu tarif kamar rata-rata, jumlah hotel, jumlah hari dan tingkat hunian.

Maka dapat dihitung potensi Pajak Hotel dengan menggunakan rumus yang disampaikan oleh Harun (2003) dalam Sulistyo (2013) sebagai berikut:

Potensi Pajak= A x B x C x D x E Keterangan :
A : Jumlah kamar hotel
B : Tarif kamar rata-rata
$\mathrm{C}:$ Jumlah hari dalam 1 tahun
D : Tingkat hunian kamar
E : Tarif pajak hotel (10\%).

\section{Analisis Perhitungan Efektivitas Pajak Hotel}

Cara untuk mengukur efektivitas pemungutan pajak adalah sebagai berikut: (Sugiarto dkk, 2015)

Efektivitas $=\frac{\text { Realisasi Penerimaan Pajak Hotel }}{\text { Potensi Penerimaan Pajak Hotel }} \times 100 \%$

Tingkat efektifitas dapat digolongkan kedalam beberapa kategori yaitu:

\section{Jumlah Hotel dan Jumlah Kamar Hotel}

1. Hasil perbandingan tingkat pencapaian diatas 100 persen berarti sangat efektif

2. Hasil perbandingan tingkat pencapaian 100 persen berarti efektif

3. Hasil perbandingan tingkat pencapaian dibawah 100 persen berarti tidak efektif. 


\section{Analisis Perhitungan Kontribusi di Kota YogyakartaTahun 2011-2015}

Untuk mengetahui seberapa besar kontribusi yang dapat disumbangkan dari Pajak Hotel terhadap pendapatan asli daerah Kota Yogyakarta dapat digunakan rumus sebagai berikut : (Pujiasih dan Wardani, 2014)

\begin{tabular}{|c|c|c|c|c|}
\hline No & Tahun & Jenis Hotel & $\begin{array}{c}\text { Jumlah } \\
\text { Hotel }\end{array}$ & $\begin{array}{l}\text { Jumlah } \\
\text { Kamar } \\
\end{array}$ \\
\hline \multirow{2}{*}{1} & \multirow{2}{*}{2011} & - Bintang & 20 & 2028 \\
\hline & & - Non-Bintang & 203 & 4315 \\
\hline \multirow{2}{*}{2} & \multirow{2}{*}{2012} & - $\quad$ Bintang & 20 & 2040 \\
\hline & & - $\quad$ Non-Bintang & 200 & 4279 \\
\hline \multirow{2}{*}{3} & \multirow{2}{*}{2013} & - $\quad$ Bintang & 38 & 3641 \\
\hline & & - Non-bintang & 197 & 4134 \\
\hline \multirow{2}{*}{4} & \multirow{2}{*}{2014} & - $\quad$ Bintang & 43 & 4176 \\
\hline & & - $\quad$ Non-Bintang & 183 & 3790 \\
\hline \multirow{2}{*}{5} & \multirow{2}{*}{2015} & - $\quad$ Bintang & 48 & 4815 \\
\hline & & - $\quad$ Non-Bintang & 180 & 3746 \\
\hline
\end{tabular}

Sumber: BPKAD Kota Yogyakarta (2017)

Penerimaan Pajak Hotel

Kontribusi $=$

Jumlah PAD periode tertentu $100 \%$

\section{HASIL DAN PEMBAHASAN}

Apabila jumlah hotel sudah ditentukan dan pengklasifikasian jenis hotel sudah sesuai dengan di lapangan, maka dapat dihitung tarif kamar rata-rata. Berdasarkan hasil dari

\section{Analisis Perhitungan Potensi Pajak Hotel}

Analisis Potensi Pajak Hotel sangat menentukan besarnya Pajak Daerah yang dapat dipungut, dengan demikian besarnya Potensi Pajak Hotel perlu diketahui untuk menetapkan besarnya penerimaan pajak pada suatu periode.

Hal ini akan memudahkan perencaan dan mengendalikan pelaksanaan pemungutan Pajak Hotel itu sendiri untuk dimasa yang akan datang. Sebelum menghitung potensi pajak 
hotel perlu diketahui langkah-langkah yang digunakan, yaitu sebagai berikut:

1) Mengetahui jumlah hotel

2) Mengidentifikasi tipe kelas hotel (Bintang dan Non-bintang), jenis kamar hotel, jumlah kamar dan tarif kamar untuk mengetahui tarif kamar rata-rata

3) Memperoleh omzet hotel dan mengalikan dengan tarif pajak hotel

Data yang diperoleh dan dengan asumsi bahwa:

1. Jumlah hari dalam 1 tahun : 365 hari

2. Masa Pergantian Kamar : 1 x 1 hari

3. Rata-rata Tarif Kamar/Malam dan Tingkat Hunian Kamar hotel di Kota Yogyakarta

\section{Tarif Kamar Rata-rata dan Tingkat Hunian Kamar Hotel Kota Yogyakarta}

\begin{tabular}{|c|c|c|c|c|}
\hline \multirow{2}{*}{ Tahun } & \multicolumn{2}{|c|}{ Bintang } & \multicolumn{2}{c|}{ Non-Bintang } \\
& Tarif Rata-rata (Rp) & Tingkat Hunian & Tarif Rata- rata (Rp) & Tingkat Hunian \\
\hline 2011 & $1,319,426$ & 0.52 & 108,817 & 0.34 \\
\hline 2012 & $1,316,920$ & 0.57 & 109,697 & 0.34 \\
\hline 2013 & $1,086,417$ & 0.61 & 109,313 & 0.32 \\
\hline 2014 & $1,060,149$ & 0.62 & 108,626 & 0.27 \\
\hline 2015 & 979,190 & 0.61 & 108,901 & 0.29 \\
\hline
\end{tabular}

Sumber: Data Olahan (2017)

Setelah mengetahui tarif kamar rata-rata tiap hotel dan tingkat hunian kamar hotel disetiap tahunnya, dan mengetahui jumlah kamar hotel disetiap tahunnya, serta dengan menggunakan asumsi yang telah dibuat, pajak hotel yang ada pada setiap klasifikasi jenis hotel dan disetiap tahunnya. Dengan menggunakan rumus perhitungan potensi pajak hotel. Dari hasil perhitungan maka potensi pajak hotel secara keseluruhan dalam kurun waktu lima tahun dari tahun 2011-2015 adalah sebagai berikut: 
Potensi Pajak Hotel \& Persentase Pertumbuhan Di Kota Yogyakarta Tahun 2011-2015

\begin{tabular}{|c|c|c|}
\hline Tahun & Potensi Pajak Hotel (Rp) & Pertumbuhan (\%) \\
\hline 2011 & 56.613 .664 .569 & - \\
\hline 2012 & 61.718 .154 .900 & 9,02 \\
\hline 2013 & 93.350 .611 .595 & 51,52 \\
\hline 2014 & 104.244 .363 .711 & 11,67 \\
\hline 2015 & 109.293 .096 .861 & 4,84 \\
\hline
\end{tabular}

Sumber : Data Olahan, 2017

\section{Analisis Perhitungan Efektivitas Pajak Hotel}

Efektivitas digunakan untuk mengukur suatu hubungan hasil pungutan suatu pajak dengan tujuan atau potensi riil yang telah dimiliki suatu daerah. Untuk menghitung tingkat efektivitas pajak hotel di Kota Yogyakarta, dengan menggunakan rumus yang telah disebutkan pada bab sebelumnya yaitu perbandingan realisasi penerimaan pajak hotel terhadap potensi pajak hotel. Berikut perhitungan besarnya efektivitas pajak hotel di Kota Yogyakarta pada tahun 2011-2015:

Efektivitas Pajak Hotel Kota Yogyakarta Tahun 2011-2015

\begin{tabular}{|c|c|r|c|c|}
\hline Tahun & Realisasi Pajak Hotel (Rp) & Potensi (Rp) & Efektivitas (\%) & Kriteria \\
\hline 2011 & $37,859,535,936$ & $56,613,664,569$ & 66.87 & Tidak Efektif \\
\hline 2012 & $55,611,097,144$ & $61,718,154,900$ & 90.10 & Tidak Efektif \\
\hline 2013 & $68,154,540,528$ & $93,350,611,595$ & 73.01 & Tidak Efektif \\
\hline 2014 & $80,707,277,300$ & $104,244,363,711$ & 77.42 & Tidak Efektif \\
\hline 2015 & $93,196,594,318$ & $109,293,096,861$ & 85.27 & Tidak Efektif \\
\hline
\end{tabular}

Sumber: Data Olahan (2017)

menunjukkan bahwa Efektivitas pajak hotel yang terjadi di Kota Yogyakarta menunjukkan angka yang jauh dari kriteria efektif, angka efektivitas pajak hotel masih dibawah $100 \%$, dan angka efektivitas pajak hotel mengalami kenaikan dan penurunan. hal ini menunjukkan aktivitas pemungutan pajak hotel di Kota Yogyakarta masi tidak 
efektif, karena rasio antara realisasi penerimaan pajak hotel dengan potensi pajak hotel yang ada masih mempunyai selisih yang cukup besar sehingga angka rupiah dalam realiasi belum mampu mencapai potensi yang diharapkan.

\section{Analisis Perhitungan Kontribusi}

Perhitungan kontribusi dilakukan untuk mengetahui seberapa besar sumbangan pajak hotel memberikan kontribusi terhadap pendapatan asli daerah di Kota Yogyakarta dengan membandingkan penerimaan pajak hotel periode tertentu dengan penerimaan pendapatan asli daerah pada periode tertentu pula.

Kontribusi Pajak Hotel Terhadap Pendapatan Asli Daerah Kota Yogyakarta Tahun 2011-2015

\begin{tabular}{|c|c|c|c|c|}
\hline Tahun & $\begin{array}{c}\text { Penerimaan Pajak } \\
\text { Hotel }\end{array}$ & $\begin{array}{c}\text { Pendapatan Asli } \\
\text { Daerah }\end{array}$ & Kontribusi (\%) & Kriteria \\
\hline 2011 & $37,859,535,936$ & $228,870,559,645$ & 16.54 & Sangat Berkontrbusi \\
\hline 2012 & $55,611,097,144$ & $338,283,728,285$ & 16.44 & Sangat Berkontrbusi \\
\hline 2013 & $68,154,540,528$ & $383,052,140,420$ & 17.79 & Sangat Berkontrbusi \\
\hline 2014 & $80,707,277,300$ & $470,641,528,444$ & 17.15 & Sangat Berkontrbusi \\
\hline 2015 & $93,196,594,318$ & $510,548,822,809$ & 18.25 & Sangat Berkontrbusi \\
\hline
\end{tabular}

Sumber: BPKAD Kota Yogyakarta, 2017 (data sekunder)

Berdasarkan analisis perhitungan, kontribusi pajak hotel terhadap pendapatan asli daerah Kota Yogyakarta mengalami penurunan dan peningkatan pada setiap tahunnya, dilihat dari segi penetapan target peneriamaan pajak hotel yang telah ditetapkan oleh pemerintah daerah kota Yogyakarta, kontribusi pajak hotel secara garis besar masuk dalam kriteria "sangat berkontribusi" karena mencapai lebih dari 4\% disetiap tahunnya. Hal ini menunjukkan bahwa realisasi penerimaan pajak hotel mempunyai angka rupiah yang besar disetiap tahunnya dan terus mengalami kenaikan disetiap tahunnya dari pada jenis pajak daerah lainnya sehingga memberikan kontribusi yang besar pula untuk pendapatan asli daerah di Kota Yogyakarta. 


\section{SIMPULAN DAN SARAN}

\section{Simpulan}

1. Perbandingan antara potensi pajak hotel dengan realisasi penerimaan pajak hotel dalam jangka waktu lima tahun yaitu dari tahun 2011-2015 terdapat selisih yang besar, dengan potensi pajak hotel sebesar Rp. 425.219.891.636 dan realisasi penerimaan pajak hotel sebesar Rp. 335.529.045.226, maka pemerintah daerah kehilangan potensi sebesar Rp. 89.690.846.410, dan dari dua klasifikasi hotel yang ada di Kota Yogyakarta hotel bintang yang memiliki proporsi potensi yang besar daripada hotel non-bintang.

2. Hasil perhitungan efektivitas pajak hotel di Kota Yogyakarta tahun 2011-2015 dengan membandingkan antara potensi pajak hotel dengan realisasi penerimaan pajak hotel menunjukkan angka rata- rata persentase masih dibawah 100\% dengan kriteria “Tidak Efektif” sehingga dapat disimpulkan bahwa realisasi penerimaan pajak hotel di Kota Yogyakarta belum mendapatkan potensi yang maksimal,

3. Hasil perhitungan kontribusi pajak hotel terhadap pendapatan asli daerah Kota Yogyakarta tahun 2011-2015, sesuai dengan target yang telah ditetapkan pemerintah daerah menunjukkan angka persentase dengan kriteria "Sangat Berkontribusi", sehingga dapat disimpulkan bahwa kontribusi pajak hotel memberikan kontribusi yang besar pula untuk pendapatan asli daerah di Kota Yogyakarta.

\section{Saran}

Berdasarkan hasil penelitian yang menunjukkan bahwa pajak hotel di Kota Yogyakarta memiliki potensi yang cukup besar karena memiliki potensi penerimaan yang baik, namun rata-rata tingkat efektivitasnya ada pada kriteria tidak efektfif. Oleh karena itu, peneliti merekomendasikan agar:

1. Pemerintah Daerah khususnya pada Badan Pengelolaan Keuangan dan Aset Daerah Kota Yogyakarta harus mengkaji ulang untuk penetapan target penerimaan pajak hotel agar sesuai dengan potensi riil yang ada, tidak hanya berdasarkan penerimaan dari tahun-tahun sebelumnya saja, 
2. Pemerintah Daerah dalam hal ini Badan Pengelolaan Keuangan dan Aset Daerah Kota Yogyakarta untuk turun langsung ke lapangan guna memperhatikan aspek-aspek yang termasuk dalam penentuan potensi pajak hotel, seperti mengklasifikasikan kelas hotel yang lebih spesifik, tingkat penghunian kamar, tarif rata-rata kamar serta jumlah kamar hotel,

3. Peningkatan kontribusi pajak hotel terhadap pendapatan asli daerah hendaknya terus dipertahankan, dan Pemerintah Daerah harus lebih mengoptimalkan penerimaan pajak hotel, sehingga kontribusi dapat terus meningkat.

\section{Daftar Pustaka}

\section{Buku}

Mardiasmo. 2002. Otonomi Daerah dan Manajemen Keuangan Daerah, Yogyakarta: Andi 2011. Perpajakan. Edisi revisi, Yogyakarta: Andi.

Prakosa, K. B. (2005). Pajak dan Retribusi Daerah. Yogyakarta: UII Press.

Siahaan, Marihot P. 2010. Pajak Daerah dan Retribusi Daerah-Edisi Revisi. Jakarta: PT Rajagrafindo Persada.

Suandy, Erly. 2005. Hukum Pajak. Jakarta: Salemba Empat.

Sugiyono. 2007. Metode Penelitian Bisnis. Bandung: Alfabeta.

Waluyo, 2008. Perpajakan indonesia. Jakarta: Salemba Empat.

\section{Jurnal}

Ardhiansyah, D., Rahayu, S. M., \& Husaini, A.(2014).Analisis Potensi Pajak Hotel Dan Pajak Restoran Dan Kontribusinya Terhadap PAD. Malang: Universitas Brawijaya.

Ardiles. (2015). Analisis Potensi dan Kontribusi Pajak Hotel Terhadap Pendapatan Asli Daerah Pemerintah Kota Padang. Padang: Universitas Negeri Padang.

Arditia, Reza. (2012). Analisis Kontribusi dan Efektivitas Pajak Daerah Sebagai 
Sumber Pendapatan Asli Daerah Kota Surabaya. Surabaya: Universitas Negeri Surabaya.

Pujiasih dan Wardani. (2014). Analisis Potensi, Efektivitas dan Kontribusi Pajak Hotel Terhadap Pendapatan Asli Daerah Kabupaten Sleman. Yogyakarta : Universitas Sarjanawiyata Tamansiswa.

Sugiarto, Y., Danurdara, A. B., \& Rofi, N. (2015). Analisis Potensi Pajak Hotel Di Kabupaten Pemalang Jawa Tengah. Bandung: Sekolah Tinggi Pariwisata Bandung.

\section{Instansi}

Badan Pengelola Keuangan dan Aset Daerah, Target dan realisasi PAD di Kota Yogyakarta Tahun 2012-2016, Kota Yogyakarta.

Dinas Pariwisata dan Kebudayaan, Data Jumlah dan Nama Hotel di Kota Yogyakarta Tahun 2012-2016, Kota Yogyakarta.

\section{Undang-Undang/Peraturan Daerah}

Peraturan Daerah Nomor 1 Tahun 2011 Tentang Pajak Daerah.

Peraturan Pemerintah Nomor 55 Tahun 2016 Tentang Ketentuan Umum dan Tata Cara Pemungutan Pajak Daerah

Undang-Undang Nomor 28 tahun 2009 Tentang Pajak Daerah dan Retribusi Daerah.

Undang-Undang Nomor 33 Tahun 2004 Tentang Perimbangan Keuangan Antara Pemerintah Pusat dan Pemerintah Daerah.

Undang-Undang Nomor 32 Tahun 2004 Tentang Pemerintah Daerah.

\section{Internet}

http://jenishotel.info/klasifikasi-hotel-berdasarkan-bintang diakses pada tanggal 31 januari 2017 pukul 17:00

www.bphn.go.id/data/documents/perda_nomor_1_tahun_2011_tentang_pajak_daerah. pdf diakses pada tanggal 13 Oktober 2016 pukul 16:10 
www.djpk.depkeu.go.id/attach/post-no-28- tahun-2009-tentang-pajak-daerah-dan-

retribusi-daerah/UU-427-973-UU_28_Tahun_2009_Ttg_PDRD.pdf diakses pada tanggal 13 Oktober 2016 pukul 16:00.

www.negarahukum.com/hukum/pendapatan-asli-daerah.html diakses pada tanggal 13 Oktober 2016 pukul 16:15. 
